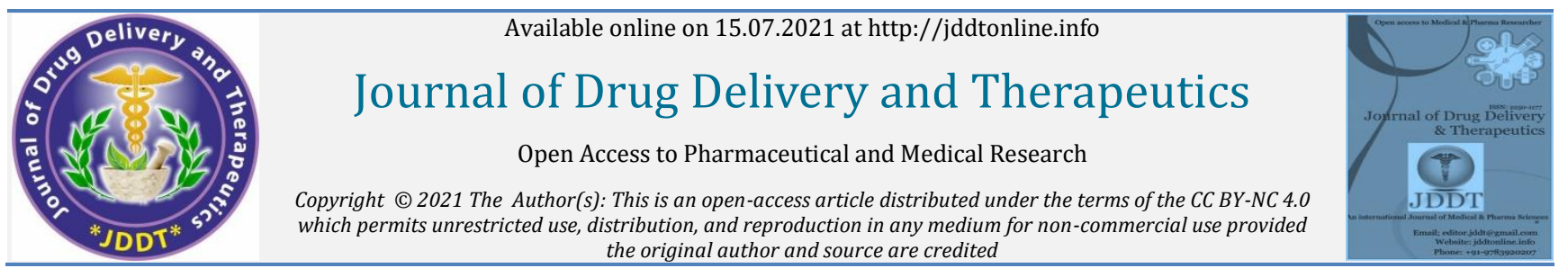

Open Access Full Text Article the original author and source are credited

Research Article

\title{
Evaluation of Antioxidant activities of Aqueous extract from Bryophyllum pinnatum on Carbon tetrachloride-induced albino rat tissues
}

\section{DALLI SMITH Yemisi Rufina ${ }^{*}$, (DALUKO Bukola Tola1, (DoWOLABI Olutunmise Victoria²}

${ }^{1}$ Department of Biochemistry, Faculty of Science, Ekiti State University, Ado- Ekiti, Nigeria

${ }^{2}$ Department of Medical Biochemistry, College of Medicine and Health Sciences, Afe Babalola University, Ado- Ekiti, Nigeria

Article Info:

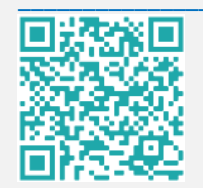

\section{Article History:}

Received 18 May 2021

Review Completed 23 June 2021

Accepted 02 July 2021

Available online 15 July 2021

\section{Cite this article as:}

Alli Smith YR, Aluko BT, Owolabi OV, Evaluation of Antioxidant activities of Aqueous extract from Bryophyllum pinnatum on Carbon tetrachlorideinduced albino rat tissues, Journal of Drug Delivery and Therapeutics. 2021; 11(4):10-15

DOI: http://dx.doi.org/10.22270/jddt.v11i4.4877

\section{*Address for Correspondence:}

ALLI SMITH Yemisi Rufina, Department of Biochemistry, Faculty of Science, Ekiti State University, Ado- Ekiti, Nigeria.

ORCID ID: https://orcid.org/0000-0003-3115-3125

\section{Abstract}

Oxidative injury or cellular damage arising from free radicals or reactive oxygen species (ROS) has been implicated in the pathogenesis of many human diseases. These ROS are generated through normal metabolism of drugs, environmental chemicals and other xenobiotics as well as endogenous chemicals. Accumulated evidence suggests that ROS can be scavenged through chemoprevention utilizing natural antioxidant compounds present in foods and medicinal plants. The aim of this study is to evaluate antioxidant activities of aqueous extract of Bryophyllum pinnatum using carbon tetrachloride-induced albino rats as model. An in-vivo antioxidant activity was carried out on the $\mathrm{CCl}_{4}$ induced rats by administration of aqueous extract of Bryophyllum pinnatum at doses of 50, 100 and $200 \mathrm{mg} / \mathrm{Kg}$ bw for 14 consecutive days, and one group was treated with Silymarin at a dose of $50 \mathrm{mg} / \mathrm{Kg}$ as a standard drug. The antioxidant activities were estimated by evaluating its effects on antioxidant parameters in the tissues of albino rats (Serum, Liver and Heart). The activity of catalase (CAT), Superoxide dismutase (SOD), Glutathione peroxidase (GPx) and the levels of MDA and GSH were evaluated in tissue homogenates. Results showed that the rats fed with the higher concentrations of Bryophyllum pinnatum had significant increase $(\mathrm{p}<0.05)$ in glutathione content $(\mathrm{GSH}), \mathrm{GPx}, \mathrm{SOD}$ and catalase activities relative to normal and standard control. However, the level of MDA was decreased $(\mathrm{p}<0.05)$ for the treated groups (100 and $200 \mathrm{mg} / \mathrm{kg}$ ). These results suggest that aqueous extracts of Bryophyllum pinnatum has active substances contributing to varied degrees of potent antioxidant activity and could serve as important source of antioxidants in food, cosmetics and pharmaceutical industries.

Keywords: Oxidative injury, Bryophyllum pinnatum, antioxidant, Diseases, Tissues

\section{INTRODUCTION}

Reactive oxygen species (ROS) are produced by cells in moderate concentrations as part of their normal physiological function. When ROS levels increase, modification to cellular components occurs ${ }^{1}$, triggering a change in the balance between ROS production and antioxidant production. This leads to an increase in oxidative stress, alteration of cellular homeostasis and inadequate functioning of various cellular pathways ${ }^{2}$. Oxidation of macromolecules such as proteins, lipids, carbohydrates and DNA is elevated in oxidative stress. Antioxidants are capable of stabilizing or deactivating, free radicals before they attack cells ${ }^{3}$. Reactive oxygen species can be eliminated by a number of enzymatic and non-enzymatic antioxidant mechanisms. The enzymatic antioxidant defenses including the superoxide dismutase (SOD), glutathione peroxidase (GPx) and catalase (CAT). Non-enzymatic antioxidants include ascorbic acid (vitamin $\mathrm{C}$ ), alpha-tocopherol (vitamin E), glutathione, carotenoids, flavonoids, and other antioxidants ${ }^{4}$. However, under oxidative stress conditions, enzymatic antioxidants may not be sufficient, and nonenzymatic antioxidants (dietary antioxidants) may be required to maintain optimal cellular functions 5 .
Antioxidants may protect cell constituents against oxidative damage and, therefore, limit the risk of various degenerative diseases associated with oxidative stress. The natural antioxidants, more recently, have attracted considerable attention of users and researchers largely on account of adverse toxicological reports on some synthetic antioxidants and growing awareness among consumers ${ }^{6}$. Bryophyllum pinnatum popularly known as Resurrection plant, air plant, cathedral bells, life plant, miracle leaf and Goethe plant is a perennial herb used in folkloric medicine in tropical Africa. It belongs to the family of crassulaceae and order of saxifragales. It is classified as weed and the plant flourishes throughout the southern part of Nigeria 7 . This study investigated the effect of Bryophyllum pinnatum on oxidative stress parameters, that is, activity levels of antioxidant enzymes (GPx, SOD and CAT) and the amount of Lipid peroxidation product (MDA) and Glutathione in the tissues of carbon tetrachloride induced albino rats.

\section{MATERIALS AND METHODS}

\subsection{Plant material}

Fresh leaves of Brytophyllum pinnatum was collected from a local farm at Ora-Ekiti, Ekiti state. The plant leaves was 
authenticated at the Herbarium section of Department of Plant science and Biotechnology, Ekiti State University (EKSU), Ado-Ekiti, Nigeria. A voucher specimen was deposited in the Department Herbarium (voucher Number: UHAE-2020/081). It was air dried at room temperature, pulverized with electric blender and then stored in a plastic container in the laboratory prior to analysis.

\subsection{Experimental animals}

A total of 30 male albino mice, $(150-200 \mathrm{~g})$ were purchased from the Laboratory Animal house Facility of College of Medicine, Ekiti State University, Ado Ekiti. They were housed in clean metal cages, with free access to water and feed. Animals were handled according to the standard guidelines of the committee on Care and Use of experimental Animal Resources which is in compliance with the National Institute of Health Guidelines for care and use of laboratory animals (Pub No. 85-23, revised 1985).

\subsection{Preparation of Brytophyllum pinnatume aqueous extract}

$100 \mathrm{~g}$ of the powdery form was dissolved in $500 \mathrm{ml}$ of distilled water for 24 hours. The crude extract was filtered with Whatman filter paper and evaporated under pressure at $60^{\circ} \mathrm{C}$ using a rotary evaporator ${ }^{8}$.

\subsection{Experimental Design}

A total of 30 male albino rats were randomized into 6 groups of 5 animals each. They were treated as follows: Group 1 (Normal control) received only distilled water and rat pellets, Group 2 (Untreated control) received $3 \mathrm{ml} / \mathrm{kg}$ body weight. Of $\mathrm{CCl}_{4}$, Group 3, 4 and 5 received $3 \mathrm{ml} / \mathrm{kg}$ body wt. Of Ccl 4 and treated with 50,100 and $200 \mathrm{mg} / \mathrm{kg}$ of aqueous extract of Bryophyllum pinnatum respectively, Group 6 received $3 \mathrm{ml} / \mathrm{kg}$ body wt. Of $\mathrm{CCl}_{4}$ and treated $50 \mathrm{mg} / \mathrm{kg}$ bwt of Silymarin a standard hepatoprotective drug for 14 days.

\subsection{Collection of blood and organs}

At the end of the experimental period, animals were anesthetized (using diethyl ether) and blood and organ samples were collected. The whole blood of each animal were collected via cardiac puncture and immediately preserved on ice cold until further processing. The blood samples were centrifuged at $3000 \mathrm{rpm}$ for $10 \mathrm{~min}$, serum from each blood sample were separated and preserved at $30{ }^{\circ} \mathrm{C}$ for further analysis. The organs needed were extracted from each animal, washed with normal saline, wiped with filter paper, weighed and preserved at $-30{ }^{\circ} \mathrm{C}$ until subsequent analysis.

\subsection{Preparation of Tissues Homogenates}

The tissues were homogenized separately in appropriate Tris-HCl buffer (100 Mm, pH 7.4) (1/5 w/v). The homogenates were centrifuged for $10 \mathrm{~min}$ at $3000 \mathrm{rpm}$ to yield a pellet that was discarded and the supernatants (homogenate) used for the various biochemical assays.

\subsection{Total Protein Determination}

The protein concentrations in the serum of the animals will be assayed, using Biuret reagent as described by ${ }^{9}$. The principle was based on the formation of purple coloured complex of cupric ion with peptide bond. An aliquot of sample $(1 \mathrm{ml})$ was put into an empty bottle. $4 \mathrm{ml}$ of biuret reagent is added. The test-tube was shaken properly and left at room temperature for $30 \mathrm{mins}$ for colour development. The absorbance was read against blank at $540 \mathrm{~nm}$.

Total protein conc. $=$ abs sample/abs standard $\times$ concentration of standard

\subsection{Estimation of lipid peroxidation Malondialdehyde (MDA)}

MDA was determined by spectrophotometry of the pink coloured product of thiobarbituric acid (TBA) reactive substances complex. Briefly, $0.1 \mathrm{ml}$ of the test sample was mixed with $0.5 \mathrm{ml}$ of $10 \%$ TCA, and $0.5 \mathrm{ml}$ of $75 \%$ TBA was then added to it. The mixture was then placed in a water bath at $80 \mathrm{oC}$ for 45 minutes. The absorbance of the resulting pink solution was measured against a reference blank of distilled water at $532 \mathrm{~nm}$.The test sample was calibrated using the MDA as a standard and the results was expressed as the amount of free MDA produced. The MDA level was calculated according to the method of ${ }^{10}$. Lipid peroxidation in units $/ \mathrm{mg}$ protein or gram tissue will be computed with a molar extinction coefficient of $1.56 \times 105 \mathrm{M}^{-1} / \mathrm{cm}$.

\subsection{Determination of Glutathione (GSH)}

Reduced glutathione was determined by the method of Ellman ${ }^{11}$.The assay is based on the oxidation of GSH by $5,5^{\prime}-$ dithiobis(2-nitrobenzoic acid) (DTNB), DTNB and glutathione (GSH) react to generate 2-nitro-5-thiobenzoic acid (TNB) which has yellow color. Therefore, GSH concentration can be determined by measuring absorbance at $412 \mathrm{~nm}$. For this assay, $50 \mu \mathrm{L}$ of the tissue homogenate was diluted in $10 \mathrm{~mL}$ of phosphate buffer $(0.1 \mathrm{M}, \mathrm{pH}$ 8). To 3 $\mathrm{mL}$ of the mixture of dilution, $20 \mu \mathrm{L}$ of DTNB $(0.01 \mathrm{M})$ was added. Absorbance is read at $412 \mathrm{~nm}$ against a blank prepared under the same conditions

\subsection{Determination Superoxide dismutase (SOD) activity}

The levels of SOD activity was determined by the method of 12. This involves inhibition of epinephrine autoxidation, in an alkaline medium at $480 \mathrm{~nm}$ in a UV vial spectrophotometer. For the determination of specific activity of SOD in homogenate sample of stomach tissue, the rate of autoxidation of epinephrine was noted at 30 seconds intervals in all groups. The enzyme activity was expressed in arbitrary units considering inhibition of autoxidation, as 1 unit of SOD specific activity.

\section{Calculation}

SOD activity $(\mathrm{U} / \mathrm{mg}$ protein $)=\mathrm{SOD}$ activity $(\mathrm{U} / \mathrm{ml}) /$ conc protein $(\mathrm{mg} / \mathrm{ml})$

\subsection{Determination Catalase activity}

This experiment was carried out using the method described by ${ }^{13} .0 .2 \mathrm{ml}$ of sample was mixed with $0.8 \mathrm{ml}$ distilled $\mathrm{H}_{2} \mathrm{O}$ to give 1 in 5 dilution of the sample. The assay mixture contained $2 \mathrm{~mL}$ of solution $(800 \mu \mathrm{mol})$ and $2.5 \mathrm{~mL}$ of phosphate buffer in a $10 \mathrm{~mL}$ flat bottom flask. $0.5 \mathrm{~mL}$ of properly diluted enzyme preparation was rapidly mixed with the reaction mixture by a gentle swirling motion. The reaction was run at room temperature. A $1 \mathrm{~mL}$ portion of the reaction mixture was withdrawn and blown into $1 \mathrm{~mL}$ dichromate/acetic acid reagent at 60 seconds intervals. The hydrogen peroxide content of the withdrawn sample was determined by the method described above. The mononuclear velocity constant, $\mathrm{K}$, for the decomposition of $\mathrm{H}_{2} \mathrm{O}_{2}$ by catalase was determined by using the equation for a first-order reaction: $\mathrm{K}=1 / \mathrm{t} \log \mathrm{S}_{0} / \mathrm{S}$, where $\mathrm{S}_{0}$ is the initial concentration of $\mathrm{H}_{2} \mathrm{O}_{2}$ and $\mathrm{S}$ is the concentration of the peroxide at $\mathrm{t}$ min. The values of the $\mathrm{K}$ are plotted against time in minutes and the velocity constant of catalase $K_{(0)}$ at 0 min determined by extrapolation. The catalase contents of the enzyme preparation were expressed in terms of Katalasefeiahigkeit or 'Katf' according to von Euler and Josephson (1927). 


\section{Calculation}

$$
\begin{aligned}
\text { ko } & =\frac{\text { change in abs of sample }}{\text { change in abs of blnk }} \\
\text { Kat. } \mathrm{f} & =\mathrm{K}_{(0)} / \mathrm{mg} \text { protein } / \mathrm{ml}
\end{aligned}
$$

\subsection{Assay for Glutathione Peroxidise (GPx) Activity}

Glutathione peroxidase (GPx) was measured by the method described by ${ }^{14}$ Briefly, the reaction mixture contained $0.2 \mathrm{ml}$ $0.4 \mathrm{M}$ phosphate buffer ( $\mathrm{PH} 7.0$ ), $0.1 \mathrm{ml} 10 \mathrm{mM}$ sodium azide, $0.2 \mathrm{ml}$ tissue homogenized in $0.4 \mathrm{M}$ phosphate buffer $\mathrm{PH}$ 7.0. $0.2 \mathrm{ml}$ tissue homogenized in $0.4 \mathrm{M}$, phosphate buffer ,PH 7.0, $0.2 \mathrm{ml}$ reduced glutathione, $0.1 \mathrm{ml} 0.2 \mathrm{mM}$ hydrogen peroxide. The contents were incubated for $10 \mathrm{~min}$

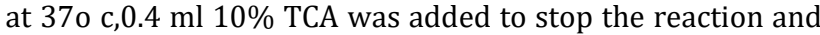

centrifuged at $3200 \times \mathrm{g}$ for $20 \mathrm{~min}$. The supernatant was assayed for glutathione content using Ellman's reagent $(19.8$ mg 5,5'-dithiobisnitrobenzoic acid [DTNB] in $100 \mathrm{ml} 0.1 \%$ sodium nitrate). The activities were expressed as $\mu \mathrm{g}$ of GSH consumed/ $\mathrm{min} / \mathrm{mg}$ protein.

\subsection{Statistical analysis}

Results were expressed as means of triplicate \pm SD. Data were statistically analyzed with Graph Pad Prism ${ }^{\circledR}$ version 6.00 by the help of turkey multiple comparison test using one way anova. Differences are considered significant when $\mathrm{P}<0.05$.

\section{RESULTS}
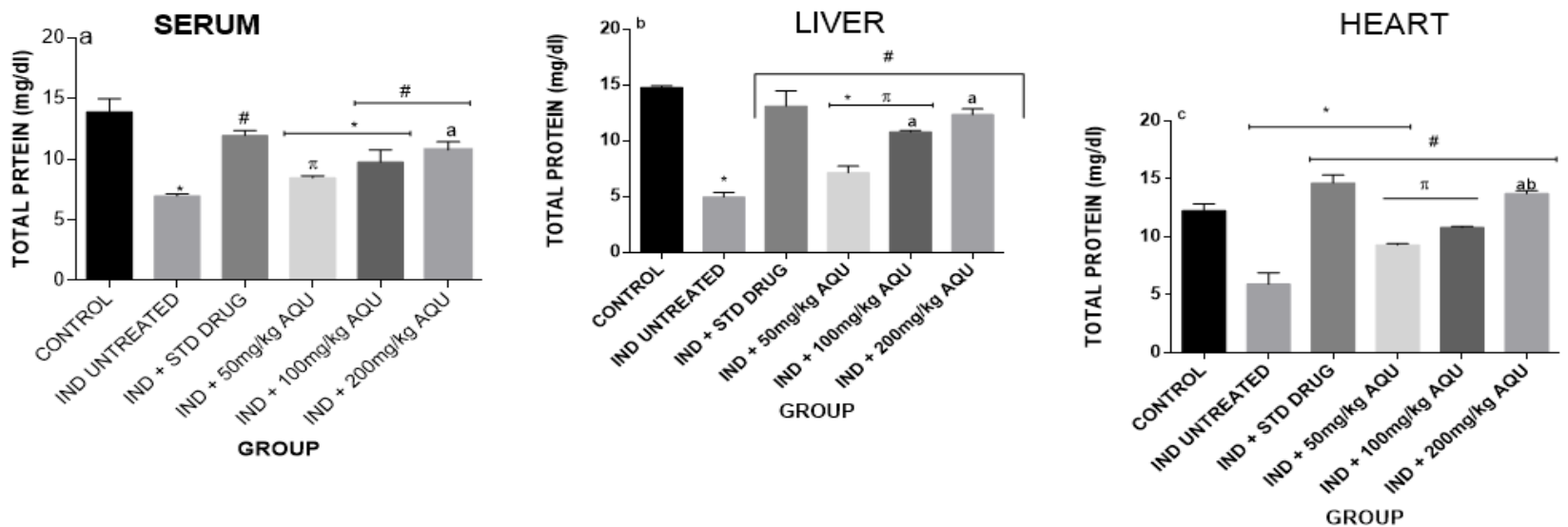

Figure 1: Effects of Aqueous extract of Bryophyllum pinnatum on Total Protein levels in the tissues (a) Serum, (b) Liver,(c)Heart of Carbon tetrachloride -induced albino rats. All values are expressed as mean \pm standard deviation of mean $(n=3$ in each group). ${ }^{*} \mathrm{P}<0.05$, vs control group, $\# \mathrm{P}<0.05$, vs CCl4 untreated group, $\pi \mathrm{P}<0.05$, vs CCl4 ind + standard drug group, aP $<0.05$, vs CCl4 ind $+50 \mathrm{mg} / \mathrm{kg}$ aqueous extract group, $\mathrm{bP}<0.05$, vs CCl4 ind $+100 \mathrm{mg} / \mathrm{kg}$ aqueous extract group group.IND:CCl4 induced; AQU: Aqueous extract of Bryophyllum pinnatum.
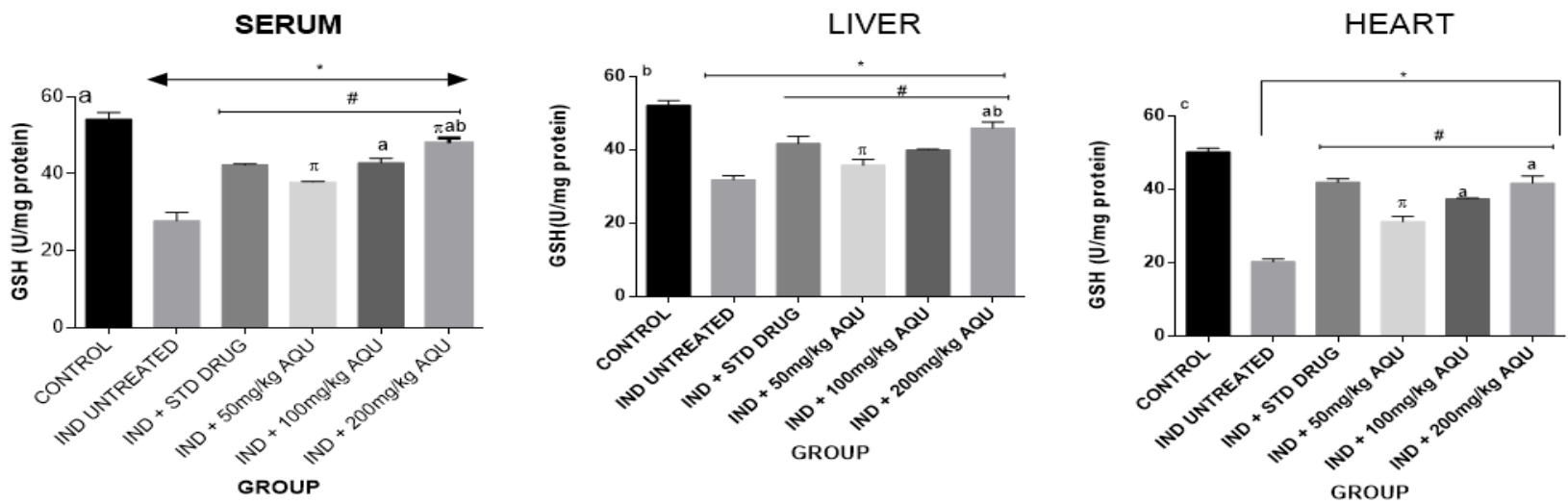

Figure 2: Effects of Aqueous extract of Bryophyllum pinnatum on GSH levels in the tissues (a) Serum, (b) Liver, (c)Heart of Carbon tetrachloride -induced albino rats. All values are expressed as mean \pm standard deviation of mean $(\mathrm{n}=3$ in each group). $* \mathrm{P}<$ 0.05 , vs control group, \#P $<0.05$, vs CCl4 untreated group, $\pi \mathrm{P}<0.05$, vs CCl4 ind + standard drug group, aP $<0.05$, vs CCl4 ind $+50 \mathrm{mg} / \mathrm{kg}$ aqueous extract group, $\mathrm{bP}<0.05$, vs CCl4 ind $+100 \mathrm{mg} / \mathrm{kg}$ aqueous extract group group.IND:CCl4 induced; AQU: Aqueous extract of Bryophyllum pinnatum; GSH: Glutathione.

The induction of the rats with $\mathrm{CCl}_{4}$ led to a significant decrease $(\mathrm{P}<0.05)$ in the concentration of total protein and GSH in all the tissues when compared with the control as shown in (Figure 1and 2). Treatment with different concentrations of the extract ameliorates the effect significantly with 100 and $200 \mathrm{mg} / \mathrm{kg}$ competing favorably with a significant increase $(\mathrm{P}<0.05)$ with the standard drug. 

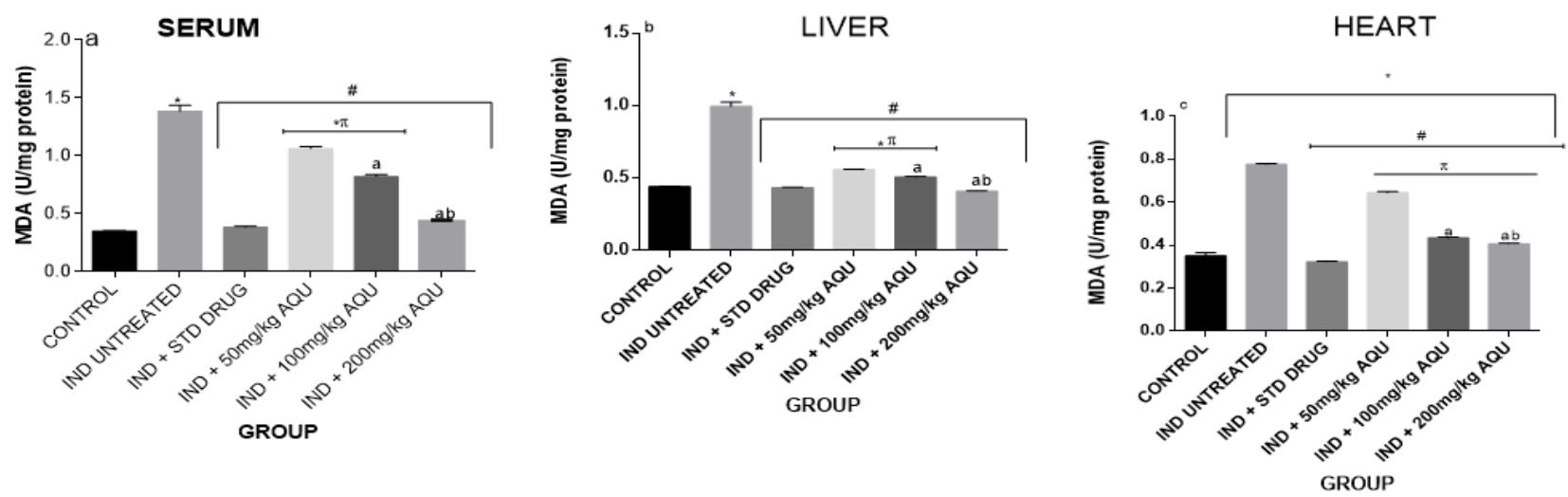

Figure 3: Effects of Aqueous extract of Bryophyllum pinnatum on MDA levels in the tissues (a) Serum, (b) Liver, (c )Heart of Carbon tetrachloride -induced albino rats. All values are expressed as mean \pm standard deviation of mean ( $\mathrm{n}=3 \mathrm{in}$ each group). ${ }^{*} \mathrm{P}<0.05$, vs control group, $\# \mathrm{P}<0.05$, vs CCl4 untreated group, $\pi \mathrm{P}<0.05$, vs $\mathrm{CCl} 4$ ind + standard drug group, aP $<0.05$, vs $\mathrm{CCl} 4$ ind + $50 \mathrm{mg} / \mathrm{kg}$ aqueous extract group, bP $<0.05$, vs CCl4 ind $+100 \mathrm{mg} / \mathrm{kg}$ aqueous extract group group. IND:CCl4 induced; AQU: Aqueous extract of Bryophyllum pinnatum; MDA: Malonydialdehyde.

The induction of the rats with $\mathrm{CCl}_{4}$ significant increased the generation of lipid peroxidation $(\mathrm{P}<0.05)$ in all the tissues (Figure 3) when compared with the control as shown in figure 2. Treatment with different concentrations of the extract inhibited lipid peroxidation as there was a significant reduction in the level of MDA towards the control values. $200 \mathrm{mg} / \mathrm{kg}$ significantly decreased $(\mathrm{P}<0.05)$ the level at the same rate as the standard drug.
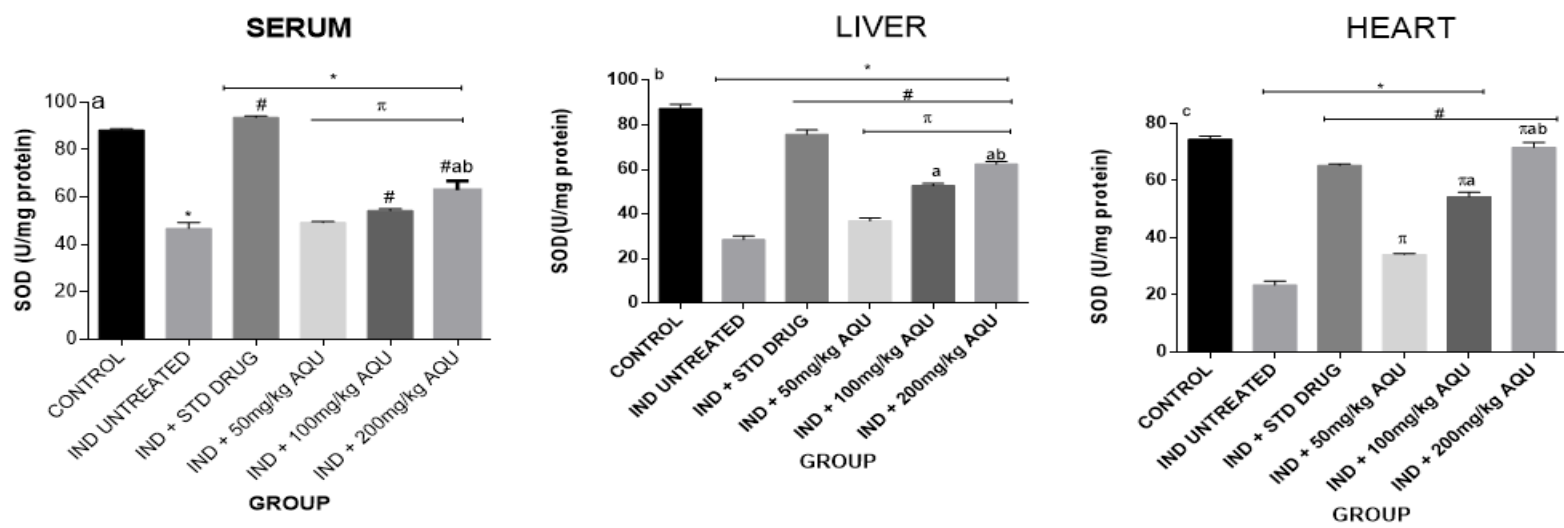

Figure 4: Effects of Aqueous extract of Bryophyllum pinnatum on the activity of SOD in the tissues (a) Serum, (b) Liver, (c) Heart of Carbon tetrachloride -induced albino rats. All values are expressed as mean \pm standard deviation of mean ( $\mathrm{n}=3 \mathrm{in}$ each group). ${ }^{*} \mathrm{P}<0.05$, vs control group, $\# \mathrm{P}<0.05$, vs CCl4 untreated group, $\pi \mathrm{P}<0.05$, vs CCl4 ind + standard drug group, aP $<0.05$, vs CCl4 ind + $50 \mathrm{mg} / \mathrm{kg}$ aqueous extract group, $\mathrm{bP}<0.05$, vs CCl4 ind $+100 \mathrm{mg} / \mathrm{kg}$ aqueous extract group group.IND:CCl4 induced; AQU: Aqueous extract of Bryophyllum pinnatum; SOD: Superoxide dismutase.

SERUM

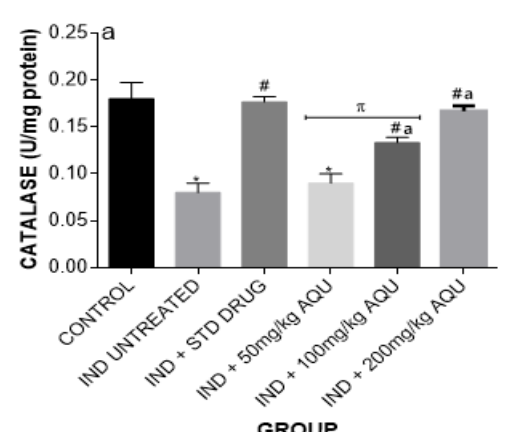

LIVER

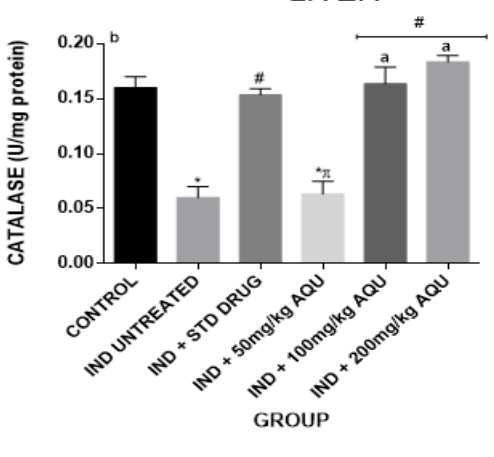

HEART

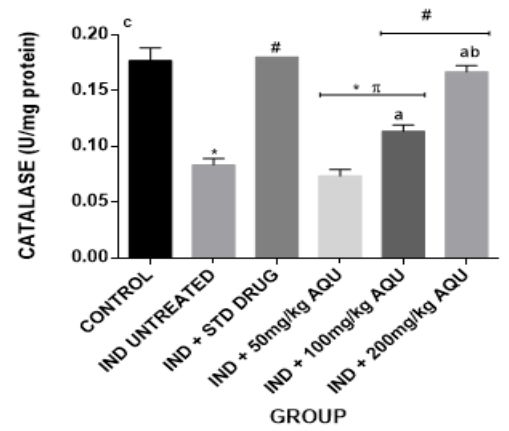

Figure 5: Effects of Aqueous extract of Bryophyllum pinnatum on the activity of Catalase in the tissues (a) Serum, (b) Liver, (c )Heart of Carbon tetrachloride -induced albino rats. All values are expressed as mean \pm standard deviation of mean $(n=3$ in each group). ${ }^{*} \mathrm{P}<0.05$, vs control group, $\# \mathrm{P}<0.05$, vs CCl4 untreated group, $\pi \mathrm{P}<0.05$, vs CCl4 ind + standard drug group, aP $<0.05$, vs CCl4 ind $+50 \mathrm{mg} / \mathrm{kg}$ aqueous extract group, $\mathrm{bP}<0.05$, vs CCl4 ind $+100 \mathrm{mg} / \mathrm{kg}$ aqueous extract group group.IND:CCl4 induced; AQU: Aqueous extract of Bryophyllum pinnatum. 

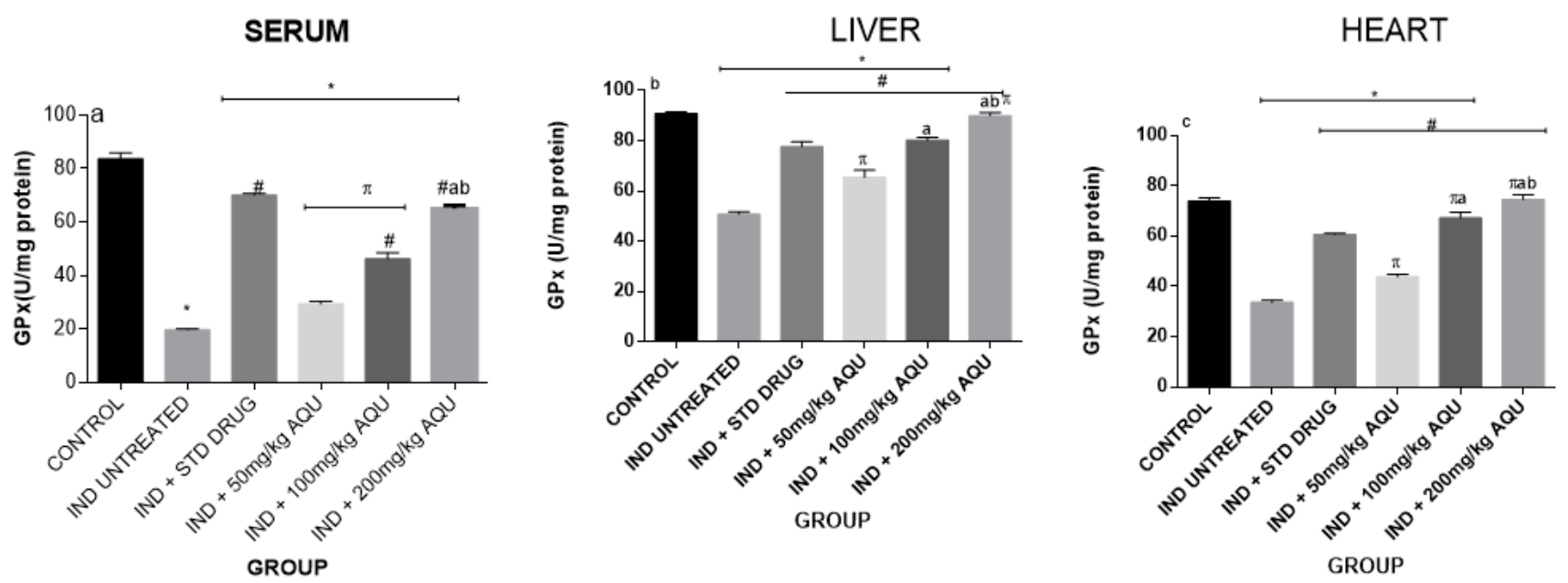

Figure 6: Effects of Aqueous extract of Bryophyllum pinnatum on the activity of GPx in the tissues (a) Serum, (b) Liver, (c) Heart of Carbon tetrachloride -induced albino rats. All values are expressed as mean \pm standard deviation of mean ( $\mathrm{n}=3 \mathrm{in}$ each group). ${ }^{*} \mathrm{P}<0.05$, vs control group, $\# \mathrm{P}<0.05$, vs CCl4 untreated group, $\pi \mathrm{P}<0.05$, vs CCl4 ind + standard drug group, aP $<0.05$, vs CCl4 ind + $50 \mathrm{mg} / \mathrm{kg}$ aqueous extract group,bP $<0.05$, vs CCl4 ind $+100 \mathrm{mg} / \mathrm{kg}$ aqueous extract group group.IND:CCl4 induced; AQU: Aqueous extract of Bryophyllum pinnatum; GPx: Glutathione peroxidase

The results of SOD, catalase and GPx (Figure4,5,6) revealed a significant increase $(\mathrm{P}<0.05)$ in the serum, liver and heart tissue for the groups treated with 100 and $200 \mathrm{mg} / \mathrm{kg}$ aqueous extract of Bryophyllum pinnatum when compared with the CCl4 induced untreated group.

\section{DISCUSSSION}

All aerobic organisms have defense mechanisms to protect against oxidative damage. Antioxidants are, by definition, compounds that have the ability to inhibit or prevent oxidation by electron donation 15,2 . Some of the actions of antioxidants include prevention or repair of the damage caused by ROS and RNS, as well as the elimination of free radicals ${ }^{15}$.The body has evolved a complex defence strategy to minimize the damaging effects of various oxidants. Central to this defence are the non-enzymatic and enzymatic antioxidants. These include reduced glutathione (GSH), superoxide dismutase (SOD), glutathione peroxidase (GPx), and catalase (CAT) respectively, which act in concert to protect the organism from oxidative damage ${ }^{16}$. Thus, this study evaluated the effect of the extracts on oxidative stress parameters MDA, GSH and CAT, SOD and GPx in albino rat tissues (serum, liver and Heart) where oxidative stress appears to play a crucial role.

Carbon tetrachloride (CCl4) is a colorless, volatile, non-inflammable liquid that is produced by the mixture of chlorine with chloroform in the presence of light. CCl4 toxicity develops not due to the $\mathrm{CCl} 4$ itself but for the generation of free radical $\mathrm{CCl} 3$ and other metabolites produced by cytochrome P450. Ultimately they lead to cellular damage by alteration of cellular structure through lipid peroxidation and in some other pathways. Severe conditions may develop through multiple organ dysfunction by these free radicals ${ }^{17}$ The observed increase in lipid peroxidation(Figure 3 ) is this study was significantly reduced $(\mathrm{P}<0.05)$ upon treatment with aqueous extract of Bryohyllum pinnatum. Plants synthesize several beneficial compounds via metabolism. The primary products of plant metabolism are proteins and cellulose. Secondary metabolic components include phenolic compounds, terpenoids, and nitrogen containing compounds ${ }^{18}$. Studies have shown the role of antioxidants (drug and plant-derived antioxidant) in scavenging free radicals and ultimately preventing oxidative stress resulting from the effects of pro-oxidants on the cells, thereby abrogating the disease-causing potentials of free radicals in the cells ${ }^{19,20}$.

Reduced glutathione (GSH) is a tripeptide, non enzymatic biological antioxidant present in the liver which helps to donate reducing equivalent to NADP+ and oxidant molecules. Decreased GSH level is associated with reduced antioxidant status in the living system. This reduction is as well linked to various diseases related to oxidative stress such are atherosclerosis, diabetes mellitus, carcinogenesis and others. The observed elevated GSH level (Figure 2) upon administration of the plant extract may depict its ability in boosting the antioxidant defence of biological system thereby preventing diseases associated with oxidative stress $^{21}$.

The activity of Catalase is one of the indices of antioxidant status of the body. Decrease in the activity of this enzyme may lead to deleterious effects as a result of superoxide and hydrogen peroxide assimilation ${ }^{22}$. Increased catalase $(\mathrm{P}<$ 0.05)activity observed in the present study (Figure 5)in all the tissues could be an indication of chemopreventive potential of the plant in the pathogenesis of oxidative stressrelated diseases which may be associated to the presence of various bioactive principles in the plant such as alkaloids, flavonoids, saponins, tannins, carbohydrates, cardioactive glycosides, steroids, phenols and reducing sugars ${ }^{23}$. This is in consonant with the report given by ${ }^{20}$, in a study on the effect of Annona muricata in rats.

Also, elevated activities of superoxide dismutase (SOD) and Glutathione peroxidase (GPx) in groups administered $100 \mathrm{mg} / \mathrm{kg}$ and $200 \mathrm{mg} / \mathrm{kg}$ (Figure 4,6 ) could depict that the extract at these doses may be effective in combating rapid generation of free radicals in the body system. GPx plays a pivotal role in $\mathrm{H}_{2} \mathrm{O}_{2}$ catabolism and in the detoxification of endogenous metabolic peroxides and hydroperoxides which catalyses GSH. Decreased activity of GPx may result from radical induced inactivation and glycation of the enzymes ${ }^{24}$. In the rats treated with Bryophyllum pinnatum extract, significant increase $(\mathrm{P}<0.05)$ in $\mathrm{GPx}$ was observed. This might reflect the antioxidant potency of the extract by preventing glycation and inactivation of GPx. Similar effect to the control group in the tissues may be indicative of the 
safety intake of Bryophyllum pinnatum extract at such concentrations

\section{CONCLUSION}

The present study was carried out to evaluate the Antioxidant activity of aqueous extracts prepared from the leaves of Bryophyllum pinnatum, this activity was tested in vivo using Albino Wistar rats. The results showed that oral administration of extracts 50,100 and $200 \mathrm{mg} / \mathrm{kg}$ body weight) led to increased antioxidant capacity in the tissues and caused amelioration in the liver and heart antioxidant status, by decreasing the MDA concentration and increasing the rate of reduced glutathione (GSH), Superoxide dismutase(SOD), Catalase(CAT) and Glutathione peroxidase activity. It could be deduced that the aqueous leaf extract of Bryophyllum pinnatum possess significant antioxidant capacity which could be good scavenger of free radicals and invariably useful in the prevention of oxidative stress related diseases. It could serve as an excellent antioxidant agent.

\section{Conflicts of Interest:}

The Authors declare that there is no conflict of interest.

\section{REFERENCES}

1. Birben EU, Murat C, Sackesen SE, \& Kalayci O, "Oxidative Stress and antioxidant defense". World Allergy Organization Journal, 2012; 5:9-19.

https://doi.org/10.1097/WOX.0b013e3182439613

2. LoboVA, Patil AP, \& Chandra N, (2010). "Free radicals, antioxidants and functional foods: impact on human health", Pharmacognosy Reviews, 2010; 4:118-126. https://doi.org/10.4103/0973-7847.70902

3. Sisein EA, "Biochemistry of Free Radicals and Antioxidants" Sch Acad J Biosci, 2014; 2:110-118.

4. Jurkovič S, Osredkar J, Marc J, "Molecular impact of glutathione peroxidases in antioxidant processes" Biochemia Medica , 2008; 18 :162-174. https://doi.org/10.11613/BM.2008.016

5. Kurutas EB, "The importance of antioxidants which play the role in cellular response against oxidative/nitrosative stress: current state" Nutrition Journal, 2016; 15:1-71. https://doi.org/10.1186/s12937-016-0186-5

6. Ramalakshmi K, RahathKI, Rao LJM, "Antioxidant potential of lowgrade coffee beans" Journal of Food Science, 2007; 41:96-103 https://doi.org/10.1016/j.foodres.2007.10.003

7. Lans CA, "Ethnomedicines used in Trinidad and Tobago for urinary problems and diabetes mellitus" J. Ethnobiol. Ethnomed, 2006; 2:1-11. DOI: https://doi.org/10.1186/1746-4269-2-45

8. Bailey CJ and Day, "Traditional plant medicines as treatments for diabetes" Diabetes Care, 1989; 12: 553-564. https://doi.org/10.2337/diacare.12.8.553

9. Gornall AG, Bardawill CJ \& David MM, "Determination of serum proteins by means of the biuret reaction" J. Biol. Chem., 1949; 177:751-66. https://doi.org/10.1016/S0021-9258(18)57021-6

10. Adam-vizi V, Seregi M, "Receptor dependent stimulatory effect of noradrenaline on $\mathrm{Na}+\mathrm{K}+$ ATPase in rat brain homogenate: Role of lipid peroxidation" Biochem.Pharmacol., 1982; 31:2231-2236 https://doi.org/10.1016/0006-2952(82)90106-X

11. Ellman G, "Tissue sulfhydryl groups" Arch Biochem Biophys, 1959; 82: 70 -77. https://doi.org/10.1016/00039861(59)90090-6

12 Misra HP, Fridovich, I "The role of superoxide anion in the autoxidation of epinephrine and a simple assay for superoxide dismutase" Journal of Biological Chemistry, 1972; 247:31703175. https://doi.org/10.1016/S0021-9258(19)45228-9

13. Sinha AK. Colorimetric assay of catalase. Anal Biochem. 1972; 47:389-394. https://doi.org/10.1016/0003-2697(72)90132-7

14. Rotruck JT, Pope AL, Ganther HE, Swanson AB, Hafeman DG, and Hoekstra WG, "Selenium: Biochemical Role as a Component of Glutathione Peroxidase" Science, 1973; 179(4073):588-590. https://doi.org/10.1126/science.179.4073.588

15. Al-Jaber NA, Awaad AS, \& Moses JE, "Review on some antioxidant plants growing in Arab world" Journal of Saudi Chemical Society. 2011; 15:293-307. https://doi.org/10.1016/j.jscs.2011.07.004

16. Magdi N, Ashour Dawoud F, Habib Rafaat A, Hanna Mahmoud A, El-Dabaa T, "Beneficial Effects of Curcumin and Ruta Chalepensis on the Antioxidant System and Inflammation in Hypercholesteromic Rats" Australian Journal of Basic and Applied Sciences , 2011; 5:2562-2567.

17. Manno M, Rezzadore M, Grossi M, Sbrana C, "Potentiation of occupational carbon tetrachloride toxicity by ethanol abuse" Hum Exp Toxicol., 1996; 15(4):294-300. PMID: 8845218 https://doi.org/10.1177/096032719601500404

18. Borrelli, GM \& Trono D, "Molecular Approaches to Genetically Improve the Accumulation of Health-Promoting Secondary Metabolites in Staple Crops-A Case Study: The Lipoxygenase-B1 Genes and Regulation of the Carotenoid Content in Pasta Products" International Journal of Molecular Sciences, 2016; 17:1-33. https://doi.org/10.3390/ijms17071177

19. Hamid AA, Aiyelaagbe 0 0, "Antioxidants: Its medicinal and pharmacological applications" AJPAC 2010; 4(8):142-151.

20. Nwaneri-Chidozie VO, Idoko, VO, Salemcity AJ, "Assessment of Antioxidant Activity of Ethanol and n-Hexane Seed Extracts of Annona muricatain Rats" JJBS 2016; 9:4-15

21. Arivazhagan S, Balasenthil S, Nagini S, "Garlic and neem leaf extracts enhance hepatic glutathione and glutathione dependent enzymes during $\mathrm{N}$-methyl- $\mathrm{N}$ nitrosoguanidine (MNNG)induced gastric carcinogenesis" Phytotherapy Research, 2000; 1: 291-293. https://doi.org/10.1002/10991573(200006)14:4<291::AID-PTR570>3.0.CO;2-Y

22. Oyedemi So, Bradley G, Afolayan AJ "In -vitro and In-vivo antioxidant activities of aqueous extract of Strychnos henningsii Gilg" AJPP, 2010; 4(2):70-78.

23. Oloyede GK, Onocha PA, Soyinka J, "Phytochemical screening, antimicrobial and antioxidant activities of four Nigerian medicinal plants" Ann Biol Res, 20101(2):114-120.

24. Sozmen EY, Sozmen B, Delen Y, Onat T,"Protective effect of Raphanus sativus extract against copper sulphate toxicity in Ctenopharyngodon idella fish" Arch Med Res, 2001; 32:283-287. https://doi.org/10.1016/S0188-4409(01)00285-5 